\title{
PENGGUNAAN BAHASA DAERAH SEBAGAI BAHASA PENGANTAR DI KELAS RENDAH SEKOLAH DASAR DI KOTA PALANGKA RAYA
}

\author{
(The Use of Local language as an Instructional Language \\ in Elementary Schools's Early Grades in Palangka Raya)
}

\author{
Muston N.M. Sitohang \\ Balai Bahasa Kaliamantan Tengah \\ Jalan Tingang Km 3,5, Palangka Raya, Kalimantan Tengah, Indonesia \\ Po-sel: muston.sitohang@kemdikbud.go.id
}

\begin{abstract}
Abstrak: Penggunaan bahasa Indonesia sebagai bahasa pengantar pada dunia pendidikan merupakan suatu keharusan. Namun, ada kalanya pada kasus-kasus tertentu pemanfaatan bahasa daerah sangat dibutuhkan guru dalam rangka membangkitkan komunikasi dengan siswa. Penelitian ini ialah penelitian deskriptif. Tujuan dari penelitian ini adalah untuk mengetahui penggunaan bahasa daerah sebagai bahasa pengantar di tingkat sekolah dasar. Temuan menunjukkan bahwa guru di kelas-kelas rendah, yaitu kelas 1 sampai dengan kelas 3, pada tingkat sekolah dasar masih menggunakan bahasa daerah sebagai pengantar selain bahasa Indonesia. Menurut sebagian responden, penggunaan bahasa daerah sangat membantu mereka dalam memberikan pemahaman kepada siswa.
\end{abstract}

Kata Kunci: bahasa daerah, Dayak Ngaju, pembelajaran.

\begin{abstract}
The use of bahasa Indonesia as the language of instructional in the education process is a must. However, sometimes in some cases the use of local language are needed by teachers in order to encourage better communication to students. This is a descriptive research. The purpose of the paper is to know the use of local language as the language of instruction at the primary school level. The findings of this study indicate that teachers in the early grades, first to third grade, at the primary school level still use local language as an introduction other than Indonesian. In accordance with most respondents, local language is very helpful for them in providing and building deeper understanding to students.
\end{abstract}

Keywords: mother language, Dayak Ngaju, education process

\section{PENDAHULUAN}

Bahasa daerah memiliki peran penting dalam kehidupan masyarakat karena keberadaannya sangat dihormati oleh negara sebagai salah satu kekayaan nasional. Oleh karena itu, bahasa daerah yang ada perlu dijunjung tinggi sebagai tanda rasa cinta kepada negara. Bahasa daerah juga diharapkan diajarkan di setiap jenjang pendidikan, khususnya di sekolah dasar.

Proses pembelajaran di kelas tentu tidak akan dapat berjalan lancar tanpa disertai penggunaan bahasa Indonesia yang baik. Penggunaan bahas Indonesia yang baik akan bermanfaat dalam menyampaikan informasi pembelajaran dari guru ke siswa dan sebaliknya. Dalam Undang-Undang Nomor 24 Tahun 2009 ditetapkan bahwa bahasa Indonesia wajib digunakan dalam peraturan perundang-undangan, dokumen resmi negara, pidato resmi presiden, wakil presiden, dan pejabat negara yang lain yang disampaikan di dalam atau di luar negeri, pengantar dalam pendidikan nasional, pelayanan administrasi publik, nota kesepahaman atau perjanjian, forum resmi 
yang bersifat nasional atau forum resmi yang bersifat internasional di Indonesia, komunikasi resmi di lingkungan kerja pemerintah dan swasta, laporan setiap lembaga atau perseorangan kepada instansi pemerintahan, penulisan karya ilmiah dan publikasi karya ilmiah di Indonesia, nama geografis di Indonesia, rambu umum, penunjuk jalan, fasilitas umum, spanduk, dan alat informasi lain yang merupakan pelayanan umum, dan informasi melalui media massa (2009). Dalam kelima belas ranah penggunaan itu, bahasa daerah (dan/atau bahasa asing) dapat digunakan juga untuk mendukung fungsi bahasa Indonesia hingga batas tertentu. Dalam hal layanan publik, misalnya, bahasa daerah dan bahasa asing dapat menyertai penggunaan bahasa Indonesia dengan tetap mengutamakan penggunaan bahasa Indonesia. Pengutamaan itu dapat diwujudkan dalam bentuk pola urutan, ukuran tulisan, atau kemenonjolan tulisan.

Pada kenyataannya, khususnya dalam bidang pendidikan, penggunaan bahasa Indonesia tidak dapat dilakukan secara optimal. Terkhusus di daerah-daerah tertentu, penggunaan bahasa daerah dirasa perlu untuk memperlancar proses pembelajaran di dalam kelas. Ada kalanya guru pada sekolah-sekolah tertentu masih memerlukan bahasa daerah sebagai alat untuk menyampaikan materi pelajarannya. Kondisi ini umum terjadi di tingkat pendidikan dasar. Hal ini mungkin juga terjadi karena sebagian besar siswa masih kental dipengaruhi bahasa daerah. Selain itu, kemampuan siswa dalam menguasai bahasa Indonesia masih terbatas pada kosakata sederhana.

Penggunaan bahasa daerah sebagai bahasa pengantar pada kelas-kelas rendah tidak dilarang. Dalam Undang-Undang Nomor 20 Tahun 2003 tentang Sistem Pendidikan Nasional (2003), termasuk Undang-Undang Nomor 4 Tahun 1950 jo Undang-Undang Nomor 12 Tahun 1954 dan Undang-Undang Nomor 2 Tahun 1989 yang menjadi cikal bakal Undang-Undang
Nomor 20 Tahun 2003, penggunaan bahasa daerah diatur sebagai pelengkap penggunaan bahasa Indonesia yang diwajibkan dalam penyelenggaraan pendidikan nasional di Indonesia. Bahasa daerah boleh digunakan pada tahap awal pendidikan untuk menyampaikan pengetahuan dan keterampilan tertentu. Bahasa daerah mempunyi fungsi pendukung bahasa Indonesia sebagai bahasa pengantar utama dalam sistem pendidikan nasional.

Dalam politik bahasa nasional, bahasa daerah berkedudukan sebagai (1) lambang kebanggaan daerah, (2) lambang identitas daerah, dan (3) alat penghubung di dalam keluarga dan masyarakat daerah. Dalam pada itu, bahasa daerah berfungi sebagai (1) pendukung bahasa nasional, (2) bahasa pengantar di sekolah, (3) alat pengembang serta pendukung budaya daerah. Rekomendasi UNESCO tahun 1999 tentang pemeliharaan bahasa-bahasa ibu di dunia mengukuhkan kedudukan dan fungsi bahasa daerah sebagai bahasa ibu (Alwi \& Sugono, 2011, hlm. 3)

Masalah yang diangkat dalam penelitian ini adalah bagaimana penggunaan bahasa daerah, dalam hal ini Dayak Ngaju, di kelas-kelas rendah sekolah dasar sebagai bahasa pengantar dalam proses pembelajaran. Sejalan dengan masalah tersebut, tujuan penelitian ini adalah mengetahui pemanfaatan bahasa daerah di kelas-kelas rendah sekolah dasar sebagai bahasa pengantar dalam proses pembelajaran di kota Palangka Raya.

Hasil penelitian ini diharapkan dapat dijadikan sebagai masukan untuk menyikapi pembinaan dan pengembangan bahasa Indonesia dan bahasa daerah dalam proses pembelajaran sebagai bahasa pengantar dalam kelas-kelas rendah. Hasil penelitian dapat juga dijadikan pedoman untuk mempertahankan keberadaan bahasa daerah khususnya bahasa Dayak Ngaju yang frekuensi penggunaannya berkurang di kalangan pelajar. 
Palangka Raya merupakan ibu kota Provinsi Kalimantan Tengah yang letaknya berada tepat di tengah Pulau Kalimantan. Kondisi budaya dan alam yang potensial tentu saja mengundang banyak orang untuk datang ke Kota Palangka Raya. Pendatang yang terus bertambah membuat Palangka Raya menjadi hunian bagi berbagai suku bangsa dan etnis. Hal itu juga menimbulkan bahasa-bahasa daerah hidup dan berkembang di Kota Palangka Raya.

Bahasa Dayak Ngaju merupakan bahasa yang dominan dipergunakan oleh penduduk lokal Palangka Raya. Pada tiap kesempatan bahasa ini sering dipergunakan di berbagai kegiatan masyarakat baik formal maupun nonformal. Berdasarkan pengamatan penulis, pada waktu senggang atau jam istirahat guru-guru lebih sering menggunakan bahasa Dayak Ngaju dalam berkomunikasi dengan rekan sesuku.

Selain bahasa Dayak Ngaju, di Kota Palangka Raya juga hidup berdampingan bahasa daerah lain. Salah satunya bahasa Banjar. Bahasa Banjar bahkan menjadi bahasa sehari-hari yang dipergunakan oleh masyarakat kota ini. Perkembangan bahasa Banjar untuk hidup dan berkembang dengan baik di Kota Palangka Raya tidak lepas dari keterjangkauan Kota Palangka Raya dari Provinsi Kalimantan Selatan yang cukup mudah. Banyak penutur bahasa Bajar dengan mudah masuk ke Kota Palangka Raya. Bahkan, masyarakat Banjar banyak yang telah secara turun-temurun hidup di Kota Palangka Raya.

Kondisi tersebut menyebabkan siswa yang bersekolah di Kota Palangka Raya memiliki latar belakang kultural yang berbeda-beda. Sebagian besar dari mereka kurang tertarik dengan pelajaran bahasa daerah karena merasa bukan bahasa ibunya. Hal ini menjadi masalah besar bagi sekolah yang tak satu pun gurunya mengerti bahasa daerah, apalagi mengajarkannya.

Bahasa dalam bentuk apa pun ialah proses aktualisasi dari keinginan, emosi, dan pikiran-pikiran manusia agar orang lain dapat memahaminya. Bahasa menjadi alat komunikasi antara individu satu dan individu lainnya. Mereka yang menggunakan bahasa yang sama merasakan suatu ikatan batin sebagai kelompok kesukuan, kebangsaan, dan sebagainya.

Menurut Wibowo (2001) bahasa adalah sistem simbol bunyi yang bermakna dan berartikulasi (dihasilkan oleh alat ucap) yang bersifat arbitrer dan konvensional yang dipakai sebagai alat berkomunikasi oleh sekelompok manusia untuk melahirkan perasaan dan pikiran. Daerah didefinisikan sebagai tempat sekeliling atau yang termasuk di lingkungan suatu kota (wilayah dan sebagainya). Dari pengertian di atas dapat disimpulkan bahwa bahasa daerah merupakan simbol atau bunyi yang bermakna dan berartikulasi yang digunakan di lingkungan suatu kota atau wilayah yang dipakai sebagai bahasa penghubung.

Di dalam hubungannya dengan kedudukan bahasa Indonesia, bahasabahasa yang terdapat di wilayah Indonesia, seperti bahasa Bali, Bugis, Madura, dan Makasar, berkedudukan sebagai bahasa daerah. Kedudukan ini berdasarkan kenyataan bahwa bahasa daerah itu ialah salah satu unsur kebudayaan yang dilindungi oleh negara sesuai dengan bunyi penjelasan pasal 36, bab XV, UndangUndang Dasar 1945. Bahasa yang digunakan di daerah dan dipelihara oleh penuturnya tentu juga dipelihara dan dihormati oleh negara karena merupakan bagian dari kebudayaan Indonesia.

Penggunaan bahasa daerah sebagai bahasa pengantar pada dunia pendidikan diperlukan karena lebih mudah diterima anak-anak. Fungsi bahasa daerah dalam pendidikan dan pembelajaran ialah (1) pendukung bahasa nasional, (2) bahasa pengantar tingkat permulaan di sekolah dasar di daerah tertentu untuk memperlancar pengajaran bahasa Indonesia dan mata pelajaran lain, (3) alat pengembangan dan pendukung kebudayaan daerah, (4) pembentuk budi pekerti pada anak didik, dan (5) penarik minat siswa. 
Penelitian yang dilakukan oleh Seksi PAUD dan Pendidikan Inklusif, Divisi Pendidikan Dasar (2005) menyatakan bahwa anak yang mempelajari bahasa daerah pada usia dini akan memiliki keunggulan baik dari segi kebahasaan maupun nonkebahasan. Keuntungan pertama berhubungan dengan perkembangan intelektualnya. Mereka cenderung memiliki keluwesan mental, keunggulan dalam pembentukan konsepkonsep atas gejala alam di sekelilingnya, dan memiliki kemampuan mental yang lebih seragam. Ini berarti bahwa dengan belajar bahasa daerah (bahasa ibu) lebih awal anak lebih mengenal dunianya dan memiliki kemampuan konseptual dalam memaknai lingkungannya melalui bahasa. Dengan kata lain, stimulus awal pada perkembangan anak melalui pembalajaran bahasa akan memberikan keuntungan dalam perkembangan penalarannya.

Keuntungan kedua, anak akan lebih diuntungkan dengan adanya kesadaran sistem bahasa sebagai suatu gejala sosial. Ia akan lebih memahami sistem bahasa ibunya. Keuntungan ini menepiskan kekhawatiran akan terganggunya penguasaan anak-anak terhadap bahasa nasional atau bahasa internasional. Anak yang menguasai bahasa ibunya atau bahasa tempat ia berdomisili tidak akan mengalami gangguan komunikasi dalam kehidupan sehari-hari mereka.

Keuntungan ketiga, anak yang belajar bahasa daerah lebih awal akan diuntungkan dari segi pemahaman budaya. Ia akan memiliki pandangan budayanya yang lebih luas. Hal ini menguntungkannya karena akan mampu mengembangkan sikap toleransi terhadap budaya lain yang berbeda.

Fungsi bahasa pengantar adalah untuk menerangkan dan mengekspresikan serta memahami dan menghayati bahan pelajaran dalam rangka mencapai tujuan pendidikan. Dalam kegiatan pembelajaran di kelas, setiap murid perlu memperoleh kesempatan untuk belajar melalui mendengarkan, bertanya, menjawab pertanyaan, menjelaskan, mengemukakan pertanyaan, membaca atau menulis. Hal-hal tersebut akan dicapai apabila muridnya diberdayakan untuk berani berkomunikasi.

Keberanian murid dalam berkomunkasi di samping harus dibina juga perlu diperhatikan latar belakangnya, terutama yang berkaitan dengan penggunaan bahasa sehari-hari di lingkungan keluarga dan masyarakat. Tumbuhnya keberanian murid dalam mengemukakan pendapat, bertanya, dan menjawab pertanyaan di dalam kegiatan pembelajaran di dalam kelas sangatlah ditentukan oleh keterampilan berbahasanya. Guru juga perlu senantiasa memberi dorongan pada murid bahwa kegiatan berkomunikasi di dalam kelas baik lisan maupun tulis secara sadar dan terencana dapat memperkaya ilmu pengetahuan.

\section{METODE PENELITIAN}

Seperti yang dikemukakan oleh Sugiyono "penelitian desktiptif adalah sebuah penelitian yang bertujuan untuk memberikan atau menjabarkan suatu keadaan atau fenomena yang terjadi saat ini dengan menggunakan prosedur ilmiah untuk menjawab masalah secara aktual" (Sugiyono, 2009, hlm. 15). Dengan demikian dalam tulisan ini penulis beranggapan bahwa metode penelitian deskriptif sesuai dengan penelitian yang dilaksanakan oleh penulis. Karena dalam penelitian ini, penulis berusaha mendeskripsikan sebuah masalah atau fenomena penggunaan bahasa daerah pada kelas-kelas rendah pada tingkat sekolah dasar.

Sesuai dengan tujuan yang hendak dicapai penelitian ini, yakni untuk mengetahui penggunaan bahasa daerah sebagai bahasa pengantar di kelas-kelas rendah tingkat sekolah dasar khususnya penggunaan bahasa Dayak Ngaju di kota Palangka Raya, dalam penelitian ini, hanya sebagian elemen atau objek saja yang 
diteliti atau hanya meneliti elemen sampel bukan seluruh elemen populasi, maka sampel dari penelitian ini yakni sebanyak sepuluh sekolah dan sepuluh orang guru kelas.

Teknik pengumpulan data yang penulis pilih atau yang akan digunakan adalah sebagaimana yang telah dikemukakan dalam instrument penelitian. Berikut ini penulis akan menguraikan teknik pengumpulan data dan jenis data yang akan digali.

Valid atau tidaknya suatu penelitian tergantung pada jenis pengumpulan data yang dipergunakan untuk pemilihan metode yang tepat sesuai dengan jenis dan sumber data yang dalam penelitian. Tehnik pengumpulan data adalah upaya untuk mengamati variabel yang di teliti antara lain:

a. Metode angket

Angket yang digunakan oleh penulis adalah Kuesioner langsung (angket langsung) yang pada penelitian ini diberikan kepada guruguru yang menjadi sampel penelitian ini. Angket tersebut berisi daftar pertanyaan yang dikaitkan dengan bahasa pengantar yang mereka gunakan dalam menyampaikan materi pelajaran di kelaskelas rendah.

b. Observasi (pengamatan)
Observasi adalah metode ilmiah dengan pengamatan dan pencatatan dengan sistematis fenomena-fenomena yang diselidiki (Arikunto, 2006, hlm. 57). Teknik ini digunakan penulis untuk memperoleh gambaran mengenai penggunaan bahasa daerah di sekolah-sekolah yang menjadi sampel dalam penelitian ini

c. Dokumentasi

Dokumentasi adalah mencari data mengenai hal-hal atau variabel yang berupa, catatan atau transkrip, surat kabar, majalah, notulen rapat, agenda dan sebagainya. Dalam hal ini penulis mencari dan mengumpulkan data yang berasal dari catatan atau arsip-arsip tersimpan yang terkait dalam penelitian ini yaitu pemanfaatan bahasa daerah dalam proses pembelajaran di kelas-kelas rendah di sekolah yang menjadi sampel dalam penelitian ini.

\section{PEMBAHASAN}

Kondisi Penggunaan Bahasa Daerah di Tingkat SD di Kota Palangka Raya

Sekolah dasar yang mengajarkan bahasa daerah sebagai mulok yang menjadi sampel dalam penelitian ini digambarkan dalam tabel di bawah ini.

Tabel 1 Sekolah yang Mengajarkan Bahasa Daerah sebagai Mulok

\begin{tabular}{|l|l|l|}
\hline \multicolumn{1}{|c|}{ Nama Sekolah } & \multicolumn{1}{|c|}{ Bahasa Daerah yang Diajarkan } & \multicolumn{1}{c|}{ Kelas } \\
\hline SDN 3 Pahandut & Dayak Ngaju & IV-V \\
\hline SDN 1 Menteng & Dayak Ngaju & IV-V \\
\hline SDN 3 Panarung & Dayak Ngaju & IV-V \\
\hline MIN Model Palangka Raya & Tidak ada & - \\
\hline SDN 5 Menteng & Dayak Ngaju & IV-V \\
\hline SDN 7 Langkai & Dayak Ngaju & IV-V \\
\hline SDN 5 Bukit Tunggal & Dayak Ngaju & IV-V \\
\hline SDN 4 Pahandut & Dayak Ngaju & IV-V \\
\hline SDN 1 Kereng Bangkirai & Dayak Ngaju & IV-V \\
\hline SDN 1 Kalampangan & Dayak Ngaju & IV-V \\
\hline
\end{tabular}


Tabel 2 di bawah ini memperlihatkan data bahasa Dayak Ngaju jumlah siswa yang merupakan penutur

Tabel 2 Data Siswa Penutur Bahasa Daerah

\begin{tabular}{|l|l|l|}
\hline \multicolumn{1}{|c|}{ Nama Sekolah } & \multicolumn{1}{|c|}{$\begin{array}{c}\text { Bahasa Daerah } \\
\text { yang Diajarkan }\end{array}$} & \multicolumn{1}{c|}{ Jumlah ( \%) } \\
\hline SDN 3 Pahandut & Dayak Ngaju & 80 \\
\hline SDN 1 Menteng & Dayak Ngaju & 75 \\
\hline SDN 3 Panarung & Dayak Ngaju & 50 \\
\hline MIN Model Palangka Raya & Tidak ada & 1 \\
\hline SDN 5 Menteng & Dayak Ngaju & 10 \\
\hline SDN 7 Langkai & Dayak Ngaju & 50 \\
\hline SDN 5 Bukit Tunggal & Dayak Ngaju & 60 \\
\hline SDN 4 Pahandut & Dayak Ngaju & 75 \\
\hline SDN 1 Kereng Bangkirai & Dayak Ngaju & 65 \\
\hline SDN 1 Kalampangan & Dayak Ngaju & \\
\hline
\end{tabular}

Dalam tabel 3 berikut diperlihatkan data penggunaan bahasa daerah sebagai bahasa pengantar di kelas-kelas rendah (1-3) dalam proses pembelajaran di sekolah yang menjadi sampel penelitian ini

Table 3. Data Bahasa Pengantar yang Digunaakan

\begin{tabular}{|l|l|l|l|l|}
\hline \multicolumn{1}{|c|}{ Nama Sekolah } & \multicolumn{3}{c|}{ Bahasa Pengantar yang digunakan } \\
\hline SDN 3 Pahandut & Indonesia & Dayak & & \\
\hline SDN 1 Menteng & Indonesia & Dayak & Banjar & \\
\hline SDN 3 Panarung & Indonesia & Dayak & & \\
\hline MIN Model Palangka Raya & Indonesia & & Banjar & \\
\hline SDN 5 Menteng & Indonesia & Dayak & & \\
\hline SDN 7 Langkai & Indonesia & Dayak & Banjar & \\
\hline SDN 5 Bukit Tunggal & Indonesia & Dayak & & \\
\hline SDN 4 Pahandut & Indonesia & Dayak & & \\
\hline SDN 1 Kereng Bangkirai & Indonesia & & Banjar & \\
\hline SDN 1 Kalampangan & Indonesia & Dayak & & \\
\hline
\end{tabular}

Tabel 1 di atas menunjukkan sepuluh sekolah dasar mengajarkan bahasa daerah, dalam hal ini bahasa Dayak Ngaju. Sembilan sekolah menunjukkan bahwa mereka mengajarkan bahasa Dayak Ngaju sebagai bagian dari mata pelajaran mulok.
Hanya satu sekolah yang tidak mengajarkan bahasa daerah. Pengajaran bahasa Dayak Ngaju disampaikan pada kelas IV dan V.

Hal itu sejalan dengan keputusan Dinas Pendidikan Kota Palangka Raya bahwa bahasa daerah yang diajarkan di 
tingkat sekolah dasar adalah bahasa Dayak Ngaju. Sekolah yang tidak mengajarkan bahasa Ngaju disebabkan oleh keterbatasan guru pengajar dan jumlah siswa yang berlatar belakang Dayak Ngaju hanya sedikit (lihat tabel 2).

Pada kelas rendah, yaitu kelas I sampai III, guru secara sadar menggunakan bahasa daerah. Bahasa daerah umumnya digunakan guru untuk membantu siswa memperlancar kegiatan belajar-mengajar. Hampir semua guru yang menjadi responden penelitian ini menggunakan bahasa Indonesia dan Dayak Ngaju sebagai bahasa pengantar. Terdapat juga guru yang menggunakan bahasa Indonesia, Dayak Ngaju, dan bahasa Banjar sebagai pengantar.

\section{Contoh Penggunaan Bahasa Daerah sebagai Bahasa Pengantar dalam Pengajaran di Kelas rendah Sekolah Dasar}

Penelitian ini juga menghasilkan beberapa contoh penggunaan bahasa daerah sebagai pengantar di kelas-kelas rendah di tingkat sekolah dasar.

\section{Contoh 1}

Penggunaan bahasa pengantar saat pembelajaran berlangsung di kelas III di salah satu sekolah yang menjadi sampel penelitian ini.

Guru : eweh dia maimbit PR matematika?

Siswa A : Aku, Pak.

Guru : Buhen ikau dia mengerjakan PR?

Siswa : Hamalen matei listrik, Pak, huang huma ikei

Guru : Bah...aku jadi mambari PR tuh hari Jumat, berarti tege epat hari waktu akan manggawi. Memang bara hari jumat sampe andau tuh listrik matei huang rumah mu?

Siswa : Dia pak.

Guru : Amun klute, ikau manggawi PR huang kelas sekarang.

\section{Contoh 2}

Penggunaan bahasa pengantar saat pembelajaran berlangsung di kelas II di salah satu sekolah yang menjadi sampel penelitian ini.

Guru : Selamat pagi anak-anak

Siswa A : Selamat Pagi, Bu.

Guru : Siapa yang tahu jumlah hari dalam seminggu

Siswa : Ulun, $\mathrm{Bu}$

Guru : Amun pian tahu, coba sebutkan satu per satu

Siswa : Hari Senin, Selasa, Rabu, Kamis, Jumahat, Sabtu, Minggu, Bu. Bujur kalo Bu.

Guru : Ya Bujur. Selain itu siapa pulang yang bisa menyebutkan jumlah hari dalam sebulan.

Siswa : Ulun Bu. Bulan apa, Bu?

Guru : Coba bulan Januari.

Siswa : Ulun cobalah. Bulan Januari tu ada 30 hari, Bu.

Guru : Hayoo baluman tepat. Yang benar itu ada 31 hari.

Siswa : Iyakah, Bu. Nah, lupa ulun Bu.

Guru : Kada papa ja.

Berdasarkan contoh dialog di atas, bahasa daerah yang sering digunakan di kelas-kelas rendah pada umumnya bahasa Dayak Ngaju. Namun, tidak hanya bahasa Dayak Ngaju, terdapat pula sekolah dan guru yang menggunakan bahasa campuran antara bahasa Indonesia dan bahasa Dayak Ngaju. Pada bagian lain beberapa guru juga menggunakan bahasa Banjar. Pemilihan bahasa daerah yang dipergunakan guru dalam pengantar pelajaran dipengaruhi oleh latar belakang guru dan siswa. Jika latar belakang guru bukan berasal dari bahasa yang dipergunakan siswa jelaslah bahasa yang digunakan adalah bahasa Indonesia.

Selain sebagai bahasa pengantar, beberapa guru menggunakan bahasa daerah sebagai bahasa komunikasi kepada siswa secara individual. Hal itu dilakukan karena kadang-kadang terdapat siswa yang memerlukan pendekatan bahasa yang khusus. Beberapa guru juga mengatakan bahwa bahasa daerah lebih akrab secara emosional dan cukup membantu dalam menyampaikan materi atau hal lain kepada siswa jika dibandingan bahasa Indonesia. 


\section{PENUTUP}

Berdasarkan pembahasan di atas dapat disimpulkan bahwa penggunaan bahasa daerah di SD pada kelas-kelas rendah hanya terbatas sebagai bahasa pengantar. Penggunaannya tidak sampai menyentuh pada substansi pengajaran. Pemanfaatan tersebut dianggap mempermudah guru dan siswa dalam memahami instruksi-instruksi pembelajaran. Namun demikian, pemanfaatan bahasa Indonesia masih merupakan unsur utama.

Pelajaran bahasa daerah secara umum dilakukan pada kelas-kelas tinggi, yaitu pada kelas IV sampai dengan V. Penggunaan bahasa daerah tersebut dimasukkan dalam mata pelajaran bahasa daerah sebagai bagian dari pelajaran muatan lokal (mulok).

\section{DAFTAR PUSTAKA}

Alwi, H., \& Sugono, D. (2011). Politik Bahasa. Jakarta: Pusat Bahasa.

Arikunto, S. (2006). Prosedur Penelitian: Suatu Pendekatan Praktik. Jakarta: Rineka Cipta.

Seksi PAUD dan Pendidikan Inklusif, \& Divisi Pendidikan Dasar. (2005). Pendidikan Anak Usia Dini dan Kebijakan Keluarga Laporan Review Kebijakan: Pendidikan dan Perawatan Anak Usia Dini di Indonesia. Jakarta. Diakses melalui http://unesdoc.unesco.org/images/0013 /001385/138522ind.pdf

Sugiyono. (2009). Metode Penelitian Kuantitatif, Kualitatif dan $R \& D$. Bandung: Alfabeta.

Undang-Undang Republik Indonesia Nomor 20 Tahun 2003 tentang Sistem Pendidikan Nasional. (2003). Diakses melalui http://htl.unhas.ac.id/form_peraturan/p hoto/134453-07. UU No20 tahun 2003 ttg sistem pendidikan nasional.PDF
Undang-Undang Republik Indonesia Nomor 24 Tahun 2009 tentang Bendera, Bahasa, dan Lambang Negara, Serta lagu Kebangsaan. (2009). Diakses melalui http://badanbahasa.kemdikbud.go.id/la manbahasa/sites/default/files/UU_200 9_24.pdf

Wibowo, W. (2001). Manajemen Bahasa. Jakarta: Gramedia.

Wurm, Stephen A. (ed.). 2001. Atlas of the World's Language in Danger of Disappearing. Paris: UNESCO Publishing 